\title{
The Use of Code-Switching in The EFL Classroom of First-Grade At Junior High School
}

\author{
Ainy Mauliddiyah ${ }^{1, a^{*}}$, Ahmad Munir1,b, and Ali Mustofa ${ }^{1, c}$ \\ ${ }^{1}$ Department of English Education And Literature Education, Post Graduated of State University of Surabaya, 60213, Indonesia \\ a ainy.17070835408@mhs.unesa.ac.id; b ahmadmunir@unesa.ac.id; c alimustofa@unesa.ac.id \\ *Corresponding Author \\ Whatsapp number: [081235736924]
}

How to Cite : Mauliddiyah, A., Munir, A., Mustofa, A. (2020). The Use of Code-Switching in The EFL Classroom of First-Grade At Junior High School. International Journal for Educational and Vocational Studies, 2 (1), 143-148. DOI: https://doi.org/10.29103/ijevs.v2i1.2266

\section{ARTICLE HISTORY}

Received: 6 December 2019

Revised: 22 December 2019

Accepted: 5 January 2020

\section{KEYWORDS}

Classroom Context; Code-Switching;

Utterances;

EFL Classroom;

\begin{abstract}
Code-Switching is not only find in social contexts, but we can also find it in the context of learning English in the class. Therefore, this research aims to observe the code switching which occurs in English class by students or a teacher. This research was conducted to find out in what context do code-switching take place in English class. The data in this study was analyzed qualitatively and through several stages. The study involved the students from class $7 \mathrm{c}$ who were able to make communication and also an English teacher in this class. The data is taken from the students' and teacher's utterances and source data is taken from the result of the observation. Based on the data analysis, the results of this study indicated that code-switching occurred in several contexts. The most happened when there was making comment, another context was answering and asking questions, and also the context of opening discussion or conducting discussion activity. In conclusions, From the data of the analysis showed that the use of code-witching in English class was success, because of the interaction of teachers who always encourage and help students by doing code-switching in certain contexts of the classroom.
\end{abstract}

This is an open access article under the CC-BY-SA license.

\section{INTRODUCTION}

Code-switching is a phenomenon that we often meet in countries that use more than one language, and code-switching is also occurs in social context. Some of the people may use code-switching in every occasion in social context. Gardner-Chloros (2009) states that code-switching provides about kinds of the identify of the speaker, and the people in bilingual country always use code-switching as the conversation in their social activities.

With respect to the above paragraph, Tasnim (2018) states that one of the example of code-switching that happened in the social context is the use of code-switching in social media of Facebook and also the use of code-switching as a regular and intuitive for verbal communication. In social context, he observed the status of users in social media of Facebook and also their conversation of the active users.

Beside in social context, code-switching is also happened in classroom context. Code-switching is never separated from language and communication in the class.
In the classroom, language is having main role in every activity. The people need language in interaction with other to get the goal of communication. Based on several researchers, there are some types of code-switching. Bloom and Gumperz (cited in Eldin, 2014) recognized two types of code-switching: situational and metaphorical ones.

Code-switching happens in classroom activities that can drive students' bravery, when they do not want or difficult to use English in the classroom, especially during communication activities. Mostly in bilingual communities. This phenomenon affects our ability to communicate our thoughts, emotions and opinions to others in and around our environment. Practically, the people in Indonesia do code-switching from Bahasa Indonesia to other language. The condition in the classroom, students and teachers change over words, phrases, clauses or sentences of English, Bahasa Indonesia, and other language in their utterances. The students will switch the language, if they don't have self confidence in English classroom learning activities. 
With respect to the above condition, Horasan (2014) states that the students use code-switching in the class is relatively high, and also teachers' code-switching is even higher This study also observes the amount of the use of code switching in term of sensational levels or type of code-switching and initiation patterns, the discourse function of code switching and the perception of the switchers. The perception for all the participants that they believed it was a tool which help learning in beginner levels and used to attract attention or for jokes.

The statement above is also supported the result study of Hidayati (2016) the use of L1 or first language by students in the class activity is very useful and get the benefit of learning. The discussion focuses on teachers' awareness of the patterns and functions the code switching which may occur in teaching and learning process. It means that almost of the students in English class interaction do code-switching in each occasion. It is easy for them to make good communication in the classroom. It can be stated that they feel comfortable to do code-switching in the class.

Another study that also examined the use of code switching in the classroom like Maishara, Dieba, Ali, Intan, \& Syed (2013) in this study focuses two research questions. The first research questions is about the students' thought about the use of code-switching in English classroom interaction, and the next research question is focus the best function of students' code-switching in the English classroom interaction for ESL learner.

Furthermore, similar to the research suggesting that use of code- switching is helpful in the English classroom interaction stated by Ncoko, Osman, \& Cockcroft (2000). Code-switching does not make confuse for learners, rather using code-switching which can help a student able to speak English more quickly.. Unlike the study of Sridhar (1996) He believes that the negative side of the using first language or L1 in classroom is symbol of bad condition during teaching and learning process. It means that code-switchng is important in implication of language Sirbu (2015) identifies the implication of the language in communication that is essentially a means of language is part of communication among the members of a society in live.

Code-switching's phenomenon also occurs in the classroom context where it can be found in the most of the subjects in an English class. Code-switching in the classroom must be found in the process of studying foreign language or second language. Lin (2013) stated classroom code-switching as the alternative more than one language in the classroom used by any member of participants, for instance students, teachers or even teacher aides. Such example are trough an English classroom interaction, in which English as the second or even foreign language, are consequently switched with the first language.

It means that in the classroom context, code-switching can be performed by any participant. They can be divided in to two parts. The first is the addressor, namely the students, and the second one is the addressee namely is the teacher and friend. The classroom context includes the situation in the classroom activity, like the condition where students are discussing, the situation where the students are doing their tasks, and presentation.

Another opinion about the classroom context was also stated by Jarvis \& Robinson (1997) stated that the student interaction is also a part of classroom context which the activities are answering and asking questions, making comments or response and conducting open discussion in the class. It means that all those contexts can be found in classroom interaction from both are the teacher and students. In this context is also possible which code-switching will occur in communication between the teacher and students.

Beside the classroom context, another study of Moore (2002) stated that the interactional context can also be part of the students. It defines the gap between what a learner can and cannot do with the language, meaning that the students need the good interactional context to make a good understanding of what they are studying in English. When code-switching arises in the interactional context, the students must try to obtain what they have to do with the language. In this context, the researcher concludes that the interactional context of students' code-switching can occur when a teacher explains the material, gives tasks to students, and when a student gives tasks to the teacher.

The theories of Jarvis and Robinson about the classroom context applied by the researcher to gain the data of the study to find code-switching which happened in classroom context, because this research aims to observe the code switching which occurs in English class by students or a teacher. This research was conducted to find out in what context do code-switching take place in English class.

\section{METHODS}

This study is designed to observe code-switching of the students and teacher of SMPN 8 Surabaya. A qualitative method is employed in this research to explain the phenomena of code-switching in classroom context. This study observed the students' and teacher's code-switching during the teaching and learning activities. It figured out the use of code-switching produced in the classroom context.

\subsection{Research Subjects and Setting}

The study involved the students of class 7C. The students in this class were different from other classes. Based on the information of the English teacher, some of the students in this class had high interest in studying English. That was the reason of choosing the class as the subject of this study. The researcher did not use all students in the class as the participants for this study. The researcher selected some students who were able to make communication in the classroom actively. Moreover, the researcher used an English teacher teaching in class $7 \mathrm{C}$ as the second subject of the research. 
The setting of this research was the state junior high school of eight (SMPN 8) Surabaya which was located in the Northern part of Surabaya. The data withdrawal was taken 4 times. The students were the mixture of Javanese Madurese, Arabian as well as Chinese in which often happened code-switching during the English lesson.

\subsection{Data and Source of Data}

The data was in the form of the students' and teacher's utterances which were taken from observation and audio-video recording as the source of the data. Based on the observation, the audio and video recording, the use of code-switching conducted by the students and teacher in English classroom interaction were noted as data. The data would be analyzed to find out the context of code-switching as stated as the aim of this study.

\subsection{Data Collection Technique and Instrument}

The collected data were taken from observation as well as the audio and video recording. Observation has been obtained to get information about the facts. It was necessary done in every qualitative approach. It was very valuable, systematic and selective way in monitoring and listening to interaction or phenomenon of code-switching that happened in an English class activity. Blaxter (1996) stated there were three phases of administering observation, those are: (1) the recording of the events, (2) the pre-specified coding the events, and (3) description the events.

The study used audio and video recording to record the first data of the students' and teacher's utterances at the main quantity of the study. The audio and video recording were the complementary to observation. Audio-visual recording facilitated the researcher in the process of data collection and analyzed since it enabled to maintain the permanence of data and understand the context of the purpose easily. Have (2007) Stated that to analyze data of interaction recording strongly needed empirical data associated with the transcript.

\subsection{Data Analysis Technique}

The existed data were transcribed with the transcription symbols, which were generally used in a conversation analysis, and based on the system developed by Allwright \& Bailey (1991, p.56-58) as shown in table 3. 1 with several modifications and adaptations.
Table 1. Modified transcription conversation and symbols used in the study of Allwright\& Bailey (1991).

\begin{tabular}{ll}
\hline Code & \multicolumn{1}{c}{ Explanation } \\
\hline$T$ & Teacher \\
$M$ & Male students, by using numbers ( M1, M2, etc) \\
& Female Students, by using numbers ( F1,F2, etc) \\
F1 & Unidentified speaking group \\
LL & Unidentified group and teacher \\
LL+T & Whole class speaking in chorus \\
LLL & Whole class and Teacher \\
LLL+T & Comments \\
[ & Emphasis \\
] & \\
Bold & \\
face & \\
\hline
\end{tabular}

\section{RESULTS AND DISCUSSION}

The researcher analyzes the utterances contain of code-switching, then find in what context that code-switching happened in English class. In this part of the result study the researcher gives the description and discussion in what context that code-switching happened in English class by using the theory of Jarvis and Robinson. Code-switching happens in some of the classroom interactional context. The following are the explanations:

\subsection{Answering and asking questions context}

The result of the observations and also the utterances of students and teacher in English class showed that code-switching was occur in this context. It can be seen in the following utterances:

1. $\mathrm{T}$ : Where is aris? adun, azahra. oh ya ndak masuk itu bahasa inggris nya apa sih, kok no no terus. ayo apa? LLL : $\quad n d a k$ tahu (laugh)

(TS-1 line 35-36)

The data of the first transcription sheet, page line 35-36, showed that the teacher did code-switching to give the explanation of what the right answered, the teacher said by asking a question to the students. In this part, code-switching occurred in the context of asking and answering questions by the teacher.

In this context Abbas et al (2016) also stated that the teacher did code-switching tried to give understanding for the students and tried to make classroom more attractive.

The other data of what the teacher also did code switching that influenced by this factor, It can be seen from the following utterances:

2. T : Ok, and has no bone. Tidak punya apa anak-anak? 
LLL : Tidak punya tulang.

(TS-1 line 77-78)

3. $\mathrm{T}$ : What kind of some adjective here. Adjective nya apa saja disini anak-anak?

LLL : banyak mom

(TS-1 line 123-124)

From the result of the utterances, the teacher did code-switching first to ask the students and check the understanding students by asking them. In here the teacher used English for the first sentences then switched in to Bahasa Indonesia and then the students also answered in to Bahasa Indonesia. It happened in the context of answering and asking questions. The result of the data above presented that the teacher still asking the questions by switching her utterances.

In this context, the students also did code-switching. It can be seen from the following utterances:

4. $\mathrm{T}$ : ok finish?

F : belum. Khan begini ya. Saya fish. My pet is fish. Khan betul ya?

$\mathrm{T}$; yes. Ok the other don't be noisy.

(TS-2 line 70 - 72)

This utterances also called tag switching. According to Hamers \& Blanc tag-switching contains implanting a tag or short phrase in one language into an utterance that is otherwise, completely in another language. classroom:

The following is Another code-swiching in the 5. T : Finish?. Could you show about your job?

LLL : No

( Chandra is asking Indra )

M1 : Opo iku?

M2 : takon pekerjaan mu

(TS-2 line $73-76$ )

The data above presented that the teacher asked the students used in English but the students didn't reply in English. The study of Abbas et al. (2016) also stated that the students prefer to use a combination of English and their national language was the best way of the instruction of the teacher. By doing the combination of English and first language the students can increase their result of the exam.

The following are the other utterances that happened in this context. The data of the utterances showed that the students talked in English and Bahasa Indonesia.

6. F : thanks Ndra.

$\mathrm{M} \quad$ : ok

$\mathrm{F} \quad$ : gini ini wes bener ya?

M : tanyako bu lily

(TS-2 line 92 - 95)

7. F : I have a fish. My fish is beautiful colour. The colour is like rainbow. Betul ya ma'am?
$\mathrm{T}$ : mana coba lihat. It's colour is rainbow begitu ya.

(TS-2 line 152-154)

From the result of the utterances in number 24 to 27 above, the students did code-switching first to ask the teacher or sometime to their friends. In here the students used English for the first sentences then switched in to Bahasa then the teacher and students also answered in to Bahasa. It happened in the context of answering and asking questions.

\subsection{Making Comment}

The second of classroom context is making comment. From the result of the observation, showed that code-switching is also happened in this context. The following are the utterances of students' code-switching happened in making comments:

8. $\mathrm{T}$ : Ok do it now. Seven person is seven students is ... you stand up in here, you stand up here, you stand up in here, you common standing here, you stand up here, you hurry up in here, you common.

F : Ayo rek maju. ( one of student ask the other member to come forward)

(TS-2 line 94-99)

9. $\mathrm{T}:$ come on alfian.

$\mathrm{M}$ : no, jangan saya ma'am

$\mathrm{T}$ : it's ok common. come here please.

M : saya ndak bisa bahasa inggris ma'am. belum selesai ma'am

(TS-2 line 119-123)

Both of the data above showed that the students did code-switching when they gave their comments. The observation presented that the students did code-switching in their utterances to make their easier to give their response.

To support this result, a previous study of Abbas et al. (2016, p 61) stated that most of the students used L1 and English to give the comments, and most of them agreed to combine both of two languages, English and also first language.

The following are the other result of the students' utterances when they use code-switching to give the response to the teacher.

10. $\mathrm{T}$ : haris what are you doing?,come here haris. Come here come forward.

M1 : yes ma'am . ndak ada sepatunya ma'am masih pakai sandal.

$\mathrm{T}$ : It's ok come here.

(TS-3 line 39-41)
11. $\mathrm{T}:$
ok. now. Who is next? common, next.
$\mathrm{M}$ : ayo majuo, kamu nak belum.
M : 


$$
\begin{array}{ll}
\text { M } & : \quad \text { nih, pakai buku ku. Tak pinjami. } \\
\mathrm{M} & : \quad \text { ndak mau. }
\end{array}
$$

(TS-4 line 15-18)

The students sometime did code-switching when they made comment in English classroom interaction. The students did comment to their friends or sometime with the teacher. The teacher made communication with the students by using English, but sometime the students answer by switching their language in to Bahasa Indonesia or sometime in Javanese.

The following are the explanation how teacher made comment by switching her language in English class interaction:

$\begin{array}{rll}\text { 12. T } & : \text { Come on, I'll check your job } \\ \mathrm{M}: & \text { No mom, belum selesai } \\ \mathrm{T}: & \text { Coba lihat } \\ \mathrm{M}: & \text { ini ma'am } \\ \mathrm{T}: & \text { ya sudah ini sudah betul tinggal } \\ & & \text { menambahan }\end{array}$

(TS-2 line 111-115)

13. T : you can choose the picture you have to describe according to the picture do you understand. why you just keep silence. are you sleepy?

$$
\begin{aligned}
& \mathrm{LL} \quad: \quad \text { no } \\
& \mathrm{T} \quad \text { : wah, ngantuk ini kalian semua. Ayo semua } \\
& \quad \text { berdiri. Stand up please. }
\end{aligned}
$$

(TS-3 line 15-18)

This result showed there was code-switching in some factors made by the teacher when she was teaching in English class. However, it doesn't mean that the teacher did not know how to speak English. She actually knew how to speak in English, however from the result of the observation sometime the teacher wanted to make easier explanation for her students use the first language than use in English.

\subsection{Conducting Open Discussion}

The result of this study, that code-switching also happened in this context. How the students or teacher conducted the discussion by switching their language. It can be seen in the following utterances:

\section{T : ok, who said yes? ayo raise your hand. \\ LL : rizky ( Some of students are Laughing ) \\ $\mathrm{T}$ : ayo raise your hand Rizky dicoba mendeskripsikan jelly fish.}

(TS-1 line 23 - 25)

15. T : why you say no. Why?, Do you know jelly fish?.

F2 : yes

$\mathrm{T}$ : Ok, yes I Know. ok coba yes I know. Why you can not describe it? You have already know about this animal. Why you say no. Ok students now pay attention to me. At the first you may know about adjective. What is Jelly fish ... using adjective?

$$
\mathrm{M} \text { : } \quad \text { no, no... no }
$$

(TS-1 line 53 - 57)

The utterances above showed that the teacher did code-switching in opening the discussion of the topic. The result showed that in this factor that trigger the occurrence of code-switching in the classroom interaction. The teacher presented the motivation for the students in the first opening discussion.

This idea is also supported by a theory of Abbas et al. (2016,p.60) where an instructor or teacher starts a discussion by using a foreign language to motivate and then change to another language to start asking for attention. from the data analysis above, showed that the teacher also did code-switching to start student discussions and encouraged students to actively start discussions together in the class in giving each other their opinions. in this case the students also did code-switching when they wanted to start discussions with their group.

\section{CONCLUSION}

The outcome from the research by Simasiku et.al (2015) is that the benefits of code-switching for teachers are to complete his/her self with the best technique for teaching the language in the classroom; the students will understand the directions efficiently

The analysis of the context of code-switching in English classroom interaction that applied by the students and teacher happened in some contexts in the classroom interaction. They are: (1) Answering and asking questions, (2) Making Comment, (3) Conducting open discussion. It can be concluded that in these contexts the students and teacher did code-switching frequently. Especially in the context of making comments. From the result of the observation the students did code-switching in these contexts, to get easier communication and to explain to the teacher or with the other friends using another language such as Bahasa and Javanese. Unlike the students' reason, the teacher used code-switching in these contexts to help the students understand what the teacher means.

\section{REFERENCES}

Abbas, A., Zahra, T., \& Shehzad, W. (2016). Code-Switching In Classroom: Exploring puposes and Needs Of Code-Switching From Students Perspective. International Conference On Interdisciplinary Social Science Studies, (November).

Allwright, D. \& K. Bailey. (1991). Focus on the Language Classroom. Cambridge: Cambridge University Press

Blaxter, M. (1996). Criteria For The Evaluation Of Qualitative Research Papers. Medical Sociology News, 22(1), 4-7.

Eldin, A. A. T. S. (2014). Socio Linguistic Study of Code 
Switching of the Arabic Language Speakers on Social Networking. International Journal of Engllish Linguistics, $\quad 4(6), \quad 78-86$. https://doi.org/10.5539/ijel.v4n6p78

Gardner, P., \& Chloros. (2009). Code-switching. In Cambridge University Press (p. 7). Cambridge University Press

Hamers, J. F., \& Blanc, M. H. a. (2002). Bilinguality and Bilingualism Second edition. In Cambridge: Cambridge University Press. https://doi.org/10.1017/CBO9781107415324.004

Have, P.t (2007). Doing conversational analysis. SAGE.

Hidayati, S. (2016). How Should Teachers View Learner Code Switching In Second /Foreign Language Classrooms? English Teaching Journal, 7(2), 83-97.

Horasan, S. (2014). Code switching in EFL classrooms and the perceptions of the students and teachers. Journal of Language and Linguistics Studies, 10(1), 31-45.

Jarvis, J. and Robinson, M. (1997) Analysing educational discourse: An exploratory study of teacher response and support to pupils' learning, Applied Linguistics 18 (2), 212-28.

Lin, A. (2013). Classroom code-switching: Three decades of research. Applied Linguistics Review, 4(1), 195-218. https://doi.org/10.1515/applirev-2013-0009

Maishara, N., Dieba, F., Ali, R., Intan, S., \& Syed, S. (2013). ESL Learners' $r$ eactions towards code switching in classroom settings. Procedia - Social and Behavioral Sciences, $\quad 90 \quad$ (Incult 2012), 478-487.https://doi.org/10.1016/j.sbspro.2013.07.117

Miles, M. B., \& Huberman, M. A. (1994). Qualitative Data Analysis. In California: SAGE Publications, Inc.https://doi.org/10.1017/S0033291715001245

Miles, M. B., Huberman, A. M., \& Saldana, J. (2014). Qualitative Data Analysis (3 ed). In United State of America: SAGE Publication (Third Edit).

Moore, D. (2002). Case Study Code-switching and Learning in the Classroom. International Journal of Bilingual Education and Bilingualism, Vol. 5, No. https://doi.org/10.1080/13670050208667762

Ncoko, S. O. S., Osman, R., \& Cockcroft, K. (2000). Codeswitching Among Multilingual Learners in Primary Schools in South Africa: An Exploratory Study. International Journal of Bilingual Education and Bilingualism, 3(4), 225-241. https://doi.org/10.1080/13670050008667709

Simasiku, L., Kasanda, C., \& Smit, T. (2015). Can code switching enhance learners' academic achievement? English Language Teaching, 8(2), 70-77. https://doi.org/10.5539/elt.v8n2p70

Sirbu, A. (2015). The Significance of Language as a Tool of Communication. "Mircea Cel Batran" Naval Academy Scientific Bulletin, 18(2), 405-406. https://doi.org/10.1080/08039480260242741
Englishes: Their Implications for Teaching ESL KAMAL. Sociolinguistics and Language Teaching, 45-70

Tasnim, Z. (2018). Nature Of Code-Switching Among The Bangladeshi Tertiary Level Facebook Users, 4(2), $709-725$.

Sridhar, K. K. (1996). Societal Multilingualism and World 